A N N A LE S

UNIVERSITATIS MARIAE CURIE-SKŁODOWSKA LUBLIN - POLONIA

VOL. XXX, 4

SECTIO J

2017

Uniwersytet Śląski w Cieszynie. Wydział Etnologii i Nauk o Edukacji

\title{
TOMASZ GEBEL
}

tomasz.gebel@gmail.com

Koordynatorzy rodzinnej pieczy zastępczej
wobec zawodowych zagrożeń

Family Foster Care Coordinator Towards Threats of Their Profession

\section{STRESZCZENIE}

Wśród wielu zmian, jakie następują w funkcjonowaniu systemu pieczy zastępczej, bardzo istotnym elementem jest pojawienie się profesji koordynatora rodzinnej pieczy zastępczej. W artykule scharakteryzowano zadania powierzane koordynatorom, faktycznie wykonywane przez nich czynności oraz problemy, z jakimi borykają się rodziny zastępcze. Empiryczna część opracowania zawiera spostrzeżenia i przekonania specjalistów zatrudnionych jako koordynatorzy na temat trudności i zagrożeń związanych ze swoją rolą zawodową. Autor prezentuje najważniejsze kierunki przekształceń oraz wyzwania stojące przed pieczą zastępczą. Wnioski mogą być przyczynkiem do projektowania zmian w lokalnych systemach wspierania rodziny.

Słowa kluczowe: piecza zastępcza; wsparcie społeczne; rodzina

\section{WPROWADZENIE}

Od 1 stycznia 2012 r. zaczęła obowiązywać ustawa z dnia 9 czerwca 2011 r. o wspieraniu rodziny i systemie pieczy zastępczej (dalej jako: ustawa o wspieraniu rodziny), która wprowadziła szereg nowych rozwiązań do obszaru systemu pomocy społecznej zajmującego się wzmacnianiem rodzin. Jedną z najistotniejszych zmian było wyodrębnienie z ustawy z dnia 12 marca 2004 r. o pomocy społecznej zadań związanych z instytucjonalną i rodzinną pieczą zastępczą oraz reorganizacja całokształtu opieki zastępczej nad dzieckiem, którą rozumie się jako całokształt działań podejmowanych w stosunku do dzieci pozbawionych opieki 
rodziców przez prawnie usankcjonowanych opiekunów, zaspokajających potrzeby dzieci, wspierających ich rozwój psychofizyczny i wspomagających ich zdrowie (Badora, Marzec 2002, s. 81). Zmiany dotyczyły działań realizowanych wspólnie przez władze samorządowe, sądy rodzinne, publiczne jednostki organizacyjne pomocy społecznej oraz organizacje pozarządowe zajmujące się wspieraniem rodzin zastępczych, czyli wszelkich form wychowania i opieki realizowanych w naturalnym środowisku rodzinnym wobec dzieci pozbawionych opieki rodziców (Wosik-Kawala [red.] 2012, s. 102). Dyktowana koniecznością lepszej ochrony praw polskich dzieci oraz zasadą prymatu rodziny i jej ochrony ustawa sformułowała na nowo tak istotne elementy, jak wymagania stawiane placówkom opiekuńczo-wychowawczym, wspieranie rodzin przeżywających kryzys, konieczność zwiększenia liczby rodzin zastępczych i pełniejszego ich wspierania. Na szczególną uwagę zasługuje wprowadzenie obligatoryjnego wsparcia w osobie asystenta rodziny dla rodzin naturalnych, którym władza rodzicielska została ograniczona, oraz zupełnie nowej profesji w obszarze systemu pieczy zastępczej - koordynatora rodzinnej pieczy zastępczej.

\section{KOORDYNATOR RODZINNEJ PIECZY ZASTĘPCZEJ - CHARAKTERYSTYKA PROFESJI}

Koordynator rodzinnej pieczy zastępczej jest swego rodzaju pracownikiem pierwszego kontaktu dla każdej rodziny zastępczej. Jest zatrudniany przez jednostkę organizacyjną systemu pieczy zastępczej zwaną organizatorem rodzinnej pieczy zastępczej. Do jego zadań należy udzielanie pomocy rodzinom zastępczym oraz wspieranie ich w opiece i wychowaniu dzieci. Wśród zadań koordynatora wyróżniono: przygotowanie - we współpracy z rodziną zastępczą i asystentem rodziny lub pracownikiem socjalnym - planu pomocy dziecku; działania zmierzające do integracji rodzinnych środowisk zastępczych; zapewnianie rodzinom zastępczym dostępu do pomocy specjalistycznej (psychologicznej, reedukacyjnej, rehabilitacyjnej); współpracę z ośrodkami adopcyjnymi oraz wspieranie pełnoletnich wychowanków rodzinnej pieczy zastępczej. Praktyka instytucji pieczy zastępczej pokazała, że koordynatorami rodzinnej pieczy zastępczej w pierwszej kolejności zostawali pracownicy socjalni, którzy do tej pory pracowali z rodzinami zastępczymi w ramach struktur Powiatowych Centrów Pomocy Rodzinie. Wykształceni i doświadczeni w świadczeniu pracy socjalnej specjaliści w największym stopniu odczuli zmiany charakteru ich pracy (Patela-Owczarek 2014, s. 19). To także oni wchodzili w relacje z rodzinami zastępczymi w oparciu o nowe zasady, ale ze starymi przyzwyczajeniami, dotychczasowymi metodami pracy, wyrobionym poglądem na swoją rolę zawodową, określonymi zależnościami na linii pracownik - klient i bagażem doświadczeń. W związku z powyższy- 
mi ustaleniami należy przyjąć, że koordynator - podobnie jak pracownik socjalny - należy do grupy profesji społecznych. Orientując swoje działania na pomoc, opiekę, animację i wychowanie, kieruje je do osób zagrożonych wykluczeniem społecznym, wykluczanych i już wykluczonych (Kantowicz 2001, s. 57).

Koordynatorem rodzinnej pieczy zastępczej może zostać osoba, która ukończyła studia wyższe na kierunku pedagogika, pedagogika specjalna, psychologia, socjologia, praca socjalna, nauki o rodzinie lub mająca dowolne wyższe wykształcenie z odpowiednimi studiami podyplomowymi oraz jeśli jej władza rodzicielska nigdy nie była ograniczona, zawieszona ani nie była tej władzy pozbawiona. Najważniejsze zmiany związane $\mathrm{z}$ charakterem pracy koordynatorów to: 1) wprowadzenie zadaniowego czasu pracy, zgodnie z którym pracownicy winni być rozliczani z wykonywanych zadań, a nie z czasu poświęcanego na pracę; pracownikom pozostawia się decyzję o godzinie rozpoczęcia i zakończenia pracy, 2) ograniczenie do 15 liczby rodzin zastępczych, które powinny być pod opieką jednego koordynatora, 3) zakaz łączenia wykonywania zawodu z zawodem pracownika socjalnego, 4) niemożność prowadzenia postępowań administracyjnych - wprowadzenie tej zasady było podyktowane zmniejszeniem administracyjnych obciążeń specjalistów pracujących z rodzinami.

Poza wymienionymi powyżej zadaniami koordynatora warto jeszcze zwrócić uwagę na szereg obowiązków wynikających z innych przepisów ustawy o wspieraniu rodziny. Należą do nich: wydawanie opinii dotyczącej możliwości powrotu dziecka pod opiekę rodziców; przygotowanie opinii o konieczności uregulowania sytuacji prawnej dziecka po upływie 18 miesięcy od chwili umieszczenia dziecka w rodzinie zastępczej, jeśli sytuacja rodziców dziecka nie uległa zmianie; uczestniczenie w posiedzeniach w sprawie dzieci umieszczonych w rodzinach zastępczych; dokonywanie oceny rodziny; przygotowywanie, wspólnie z podopiecznym i rodziną zastępczą, indywidualnego programu usamodzielnienia; przygotowywanie opinii o możliwości umieszczenia w rodzinie zastępczej większej liczby dzieci.

W ramach wypełniania obowiązków koordynator staje przed koniecznością współpracy z przedszkolami i szkołami, sądem rodzinnym i kuratorami zespołu kuratorskiej służby sądowej, poradnią psychologiczno-pedagogiczną, instytucjami opiekuńczo-wychowawczymi oraz jednostkami służby zdrowia. Jest odpowiedzialny za koordynowanie właściwego wsparcia kierowanego do rodziny zastępczej przez jej otoczenie społeczne. Bardzo trudno jest zatem zdefiniować zamknięty katalog jego zadań i obowiązków. Dodatkowym wyzwaniem jest duży wachlarz problemów, z jakimi borykają się rodziny zastępcze, które wynikają z różnorodnych przyczyn umieszczania dzieci w pieczy zastępczej. Rzecznik Praw Dziecka (Stenogram wypowiedzi RPD Marka Michalaka) wskazał na następujące przyczyny ingerencji sądów we władzę rodzicielską: choroba alkoholo- 
wa rodziców - zaniedbania opiekuńczo-wychowawcze (52\%), w tym zdrowotne i higieniczne (39\%); przemoc, w tym przemoc fizyczna, psychiczna i seksualna (36\%); trudna sytuacja materialna rodziny $(21 \%)$; brak odpowiedniego nadzoru ze strony rodziców (18\%); zaburzenia psychiczne rodziców (12\%); pozostawienie dziecka pod opieką innego członka rodziny lub w szpitalu (27\%). W 88\% badanych przez RPD przypadków co najmniej trzy wymienione problemy występowały jednocześnie, co wskazuje na duże nawarstwienie problemów, z jakimi borykają się rodziny naturalne dzieci umieszczanych w rodzinnej pieczy zastępczej, oraz dużą złożoność negatywnych skutków, z jakimi muszą radzić sobie dzieci, a tym samym opiekujące się nimi rodziny zastępcze. Potwierdzają to badania przeprowadzone wśród koordynatorów Miejskiego Ośrodka Pomocy Społecznej w Jaworznie ${ }^{1}$. Najczęstszymi problemami występującymi wśród jaworznickich rodzin zastępczych są: 1) konflikty z rodzicami naturalnymi dzieci umieszczonych w pieczy zastępczej - $66 \%$ rodzin, 2) trudności w nauce - 35\%,3) śmierć co najmniej jednego z rodziców naturalnych - 20\%, 4) brak odpowiednich kompetencji wychowawczych rodziny zastępczej - 13\%,5) śmierć rodzica zastępczego - 10\%, 6) znaczna demoralizacja dziecka umieszczonego w rodzinie zastępczej - 8\%,7) doświadczenie przemocy - 8\%, 8) zdiagnozowane zaburzenia psychiczne $-5 \%, 9)$ opieka nad dzieckiem z alkoholowym zespołem płodowym (FAS) $-3 \%, 10$ ) rozpad rodziny zastępczej $-2 \%$.

\section{SYSTEM WSPIERANIA RODZIN ZASTĘPCZYCH}

Właściwe systemowe wsparcie rodzin zastępczych mają zapewniać określone zasady funkcjonowania organizatora rodzinnej pieczy zastępczej i nałożone na niego obowiązki. Jednym $\mathrm{z}$ nich są wspomniane powyżej posiedzenia zespołu ds. oceny dziecka przebywającego w rodzinnej pieczy zastępczej. Poza koordynatorem w spotkaniu „grupy roboczej” bierze udział przedstawiciel organizatora rodzinnej pieczy zastępczej, ośrodka adopcyjnego, psycholog, rodzina zastępcza oraz rodzice biologiczni. Zespół specjalistów jest uzupełniany przez znaczące osoby z otoczenia społecznego, które mogą udzielić istotnych uwag lub mają wpływ na funkcjonowanie dziecka i rodziny, takie jak: nauczyciel, pedagog, kurator zawodowy czy asystent rodziny. Posiedzenia zespołu powinny odbywać się nie rzadziej niż co 6 miesięcy, a w przypadku dzieci poniżej 3. r.ż. nie rzadziej niż co 3 miesiące. Posiedzenie ma nie tylko funkcję kontrolną (zarówno wobec rodziny zastępczej, jak i koordynatora $\mathrm{z}$ nią pracującego), ale powinno przede wszystkim służyć wychowawczemu i merytorycznemu wsparciu rodziny zastęp-

\footnotetext{
${ }^{1}$ Na podstawie badań własnych przeprowadzonych w kwietniu 2016 r., w których wzięło udział siedmioro koordynatorów rodzinnej pieczy zastępczej, mających pod opieką w sumie 100 rodzin zastępczych.
} 
czej w jak najlepszym zaspokajaniu potrzeb dziecka, a także wspólnemu - opartemu na doświadczeniach rozmaitych specjalistów - projektowaniu działań skupionych na dobru dziecka.

Istotnym elementem zapewniania rodzinom właściwej pomocy jest wsparcie psychologiczne. Ustawa o wspieraniu rodziny nakłada na organizatorów obowiązek przeprowadzenia psychologicznych badań kandydatów na rodziców zastępczych pod kątem motywacji do pełnienia tej funkcji oraz kompetencji wychowawczych. Zarówno działalność diagnostyczno-konsultacyjna, jak i obowiązek zapewnienia badań psychologicznych mogą być realizowane przez kierowanie do innych instytucji lub $\mathrm{w}$ ramach zatrudnionego przez organizatora psychologa. Posiadaniu w zespole specjalistów psychologa przeznaczonego do wspierania rodzin zastępczych powinna sprzyjać konieczność ustawicznego diagnozowania psychologicznego rodzin zastępczych (niezawodowych, zawodowych i rodzinnych domów dziecka) - opinia dotycząca predyspozycji i motywacji powinna być wydawana przez psychologa co 2 lata.

Organizator rodzinnej pieczy zastępczej powinien także zapewnić rodzinom zastępczym możliwość: udziału w grupach wsparcia, skorzystania z pomocy wolontariuszy oraz wzmacniania swoich kompetencji przez udział w szkoleniach. Interesującą formą miękkiego wspierania rodzin zastępczych są rodziny pomocowe. Rodziną pomocową może być inna rodzina zastępcza (niezawodowa, zawodowa lub prowadzący rodzinny dom dziecka) lub inne osoby, które zostały przeszkolone do pełnienia tej funkcji. Ze wsparcia rodziny pomocowej można korzystać w okresie czasowego niesprawowania opieki nad dzieckiem (z uwagi na wypoczynek, szkolenie lub hospitalizację), nieprzewidzianych trudności lub zdarzeń losowych.

\section{ZAGROŻENIA ZAWODOWE W PRACY KOORDYNATORÓW}

Aktualne badania dotyczące realizacji zadań wynikających z ustawy o wspieraniu rodziny pokazują, że nie wszystkie powiaty są w stanie spełnić omawiane założenia (Raport z oceny realizacji ustawy o wspieraniu rodziny $i$ systemie pieczy zastępczej... 2016). Niedostatki w tworzącym się systemie pieczy zastępczej najsilniej odczują specjaliści bezpośrednio odpowiedzialni za wspieranie rodziny, czyli koordynatorzy. Koordynatorzy rodzinnej pieczy zastępczej zatrudnieni w Powiatowych Centrach Pomocy Rodzinie w województwie śląskim wskazują liczne zagrożenia związane $\mathrm{z}$ wykonywaniem swojej pracy, a tym samym z właściwym wspieraniem rodzin zastępczych. Trudności wymieniane przez koordynatorów można podzielić na kilka zasadniczych obszarów:

1. Instytucjonalne - dotyczą funkcjonowania instytucji, w ramach których działa organizator rodzinnej pieczy zastępczej. Problemami są tu: brak 
środków finansowych na podnoszenie kompetencji zatrudnionych koordynatorów oraz na fakultatywne formy wspierania rodzin zastępczych, co powoduje ograniczanie się przez organizatorów do udzielania rodzinom jedynie obligatoryjnej pomocy; wynikające z tej samej przyczyny nieprzestrzeganie przez organizatora limitu środowisk pracy przypadających na jednego koordynatora - „ograniczona możliwość wejścia w głąb rodziny - refleksji nad ich problemami”, czy „przydzielanie 15 środowisk dla pracownika zatrudnionego na pół etatu - obchodzenie prawa"; niedostatek działań instytucjonalnych zmierzających do zwiększenia liczby niezawodowych rodzin zastępczych, które są niezwykle istotne dla tworzenia bazy wykwalifikowanych i właściwie zmotywowanych rodzinnych środowisk opiekuńczo-wychowawczych, gwarantujących wysoki poziom pracy $\mathrm{z}$ dzieckiem umieszczonym $\mathrm{w}$ pieczy zastępczej, a których niedostatek często prowadzi do umieszczania małych dzieci w placówkach opiekuńczo-wychowawczych niezgodnie z obowiązującym prawem (w 2016 r. 146 dzieci w wieku 0-7 lat umieszczono w instytucjonalnej pieczy zastępczej na terenie kraju) (Informacja Rzecznika Praw Dziecka... 2016); realny brak dostępu do innych specjalistów (psycholog, terapeuta); brak czynników motywacyjnych do pracy oraz niedocenianie jej przez przełożonych; osamotnienie w działaniach i brak wsparcia dla koordynatora; obarczanie koordynatora jednoosobową odpowiedzialnością za sytuację w rodzinie - ,jeżeli rodzina źle funkcjonuje, to obarcza się za to koordynatora, na co wskazują także zarzuty pokontrolne urzędników"; niejasny system zarządzania pracą ze strony przełożonych; nadmierna biurokracja; przerzucanie zadań organizatora rodzinnej pieczy zastępczej na koordynatora; „nierozumienie przez kierowników specyfiki pracy i nakazywanie pracy w urzędniczych godzinach, oczekiwanie, iż koordynator zna się na wszystkim".

2. Międzyinstytucjonalne - dotyczą współpracy z innymi instytucjami, których zadaniem jest troska o dobro dziecka i rodziny. Do trudności zaliczane są: współpraca z sądami rodzinnymi (brak odpowiedniej ilości czasu na rzetelne zaopiniowanie kandydatów na rodziców zastępczych, wydawanie postanowień niezgodnych z opinią dotyczącą dobra dziecka, „nieprzychylność, pomijanie i bagatelizowanie negatywnych opinii koordynatora nt. kandydatów na rodzinę zastępczą oraz już funkcjonujących rodzin", nieprzekazywanie dokumentacji); skostniałe struktury MOPS, Policji (długotrwałe procedury w nagłych przypadkach, brak chęci do wspólnego prowadzenia działań w środowiskach ich potrzebujących); brak wypracowanych procedur współpracy między instytucjami; brak wiedzy o zadaniach koordynatorów i specyfice ich pracy (,wychowawczyni dziecka sugerowała koordynatorowi, żeby usunął wszy z jego 
głowy, lekarz medycyny pracy nie wiedział, kim jest koordynator rodzinnej pieczy zastępczej i czym się zajmuje"); pobieżne i ogólne opinie na temat dzieci dostarczane przez szkoły.

3. Prawne - związane z rozwiązaniami wynikającymi bezpośrednio z zapisów legislacyjnych. W przekonaniu koordynatorów problemami są: brak faktycznych narzędzi wywierania wpływu na RZ przez koordynatorów - „brak jasno określonych uprawnień i obowiązków”; „brak ujednoliconej ogólnokrajowej dokumentacji i wytycznych do pracy koordynatora". Problem ten jest także poruszany i wskazywany jako istotny w literaturze przedmiotu (Kanios 2016, s. 120).

4. Interpersonalne - dotyczą czynnika ludzkiego i relacji osobowych. Koordynatorzy zwracają uwagę na: brak chęci do współpracy ze strony pracowników socjalnych; niechęć do współpracy ze strony rodzin zastępczych (zatajanie istotnych informacji - „koordynator prowadzi pracę w innym kierunku niż powinien", niestosowanie się do zaleceń koordynatorów); niskie kompetencje wychowawcze rodzin zastępczych i niechęć do ich podnoszenia; częste postawy roszczeniowe rodziców zastępczych; postrzeganie koordynatora jedynie w kategoriach kontrolera i zagrożenia, a nie jako wsparcia; decyzje uwarunkowane „humorem” przełożonego, bierność i brak inicjatywy ze strony przełożonych, kolesiostwo i protekcja; wypalenie zawodowe wynikające z wielu czynników (duży stres, brak skuteczności własnych działań) (Fengler 2001; Szmagalski 2009; James, Gilliland 2008, s. 471-498). Negatywnie bywają też postrzegani sami koordynatorzy: przejmują odpowiedzialność za rodzinę; brak u nich elastyczności i obiektywizmu; cechuje ich nieumiejętność pracy w grupie i organizowania działań wymagających współpracy kilku jednostek, brak zaangażowania, niechęć do podnoszenia swoich kwalifikacji i konflikty interpersonalne wpływające na jakość świadczonej pracy.

Wymieniane dziś przez koordynatorów trudności i zagrożenia związane z wykonywaniem zawodu koordynatora są w dużej części tożsame z problemami zgłaszanymi przez pracowników socjalnych (Musioł, Twardowska 2011, s. 67-79), których działania zawodowe winny być w znacznej mierze usystematyzowane po latach zawodowych, instytucjonalnych i legislacyjnych doświadczeń.

\section{ZAKOŃCZENIE}

Pomimo licznych trudności nietrudno jest zauważyć wyraźną zmianę paradygmatu pracy specjalistów zajmujących się rodzinami zastępczymi. Przede wszystkim przestali być urzędnikami zajmującymi się głównie prowadzeniem postępowań administracyjnych, wypłacaniem świadczeń i kontrolowaniem wa- 
runków, w jakich przebywają dzieci. Obecnie powinni przede wszystkim towarzyszyć rodzinom zastępczym w ich codziennej roli, pełniąc głównie misję edukacyjną i wspierającą. Pomimo zatrudnienia w instytucji pełniącej funkcję organizatora rodzinnej pieczy zastępczej, powinni w niej być reprezentantem interesów rodziny. Funkcja kontrolna zarówno wobec rodziny, jak i wobec koordynatora została scedowana na starostę i nie może być realizowana przez organizatora pieczy. Wspieranie rodziny zastępczej powinno się opierać na traktowaniu jej jako równorzędnego partnera w tworzeniu dzieciom odpowiedniego środowiska opiekuńczo-wychowawczego. Skuteczna pomoc zależy nie tylko od kompetencji zawodowych koordynatorów, ale także od umiejętności nawiązania z rodziną więzi i podtrzymywania relacji. To $\mathrm{w}$ istotnej części pozostaje $\mathrm{w}$ gestii ich przełożonych, którzy muszą dostrzec potencjał w wykorzystaniu swoistego narzędzia pracy, jakim jest koordynator, we właściwy sposób.

Problemy dostrzegane przez koordynatorów mogą wynikać z innych przesłanek niż tylko z nieugruntowania profesji w zawodowym otoczeniu społecznym. Kreowany na nowo system pieczy zastępczej okazuje się być obarczony tymi samymi problemami, którymi dotknięty jest - negatywnie postrzegany, niedofinansowany i traktowany bez należytej uwagi przez polityków i samorządowców - system pomocy społecznej. Aktualna informacja Rady Ministrów o realizacji ustawy o wspieraniu rodziny (Informacja Rady Ministrów... 2017) mówi o 1643 koordynatorach (stan na 31 grudnia 2016 r.) zatrudnionych w ramach systemu pieczy zastępczej. Biorąc pod uwagę, że podmiotów rodzinnych form pieczy zastępczej, czyli potencjalnych środowisk pracy dla koordynatorów, jest 38459 , to jeden koordynator przypada na 23 rodziny zastępcze, co średnio o ponad połowę przekracza ustawowe ograniczenie. Liczba specjalistów, którzy czują się pozostawieni na uboczu systemu wsparcia rodziny, nieoferującego im dostatecznych narzędzi służących pomocy rodzinie, jest jednak niebagatelna. Rozwijający się system pieczy zastępczej i przewidywany wzrost liczby rodzin zastępczych sprawi, że i wspierających ich koordynatorów będzie musiało być więcej.

Badani koordynatorzy rodzinnej pieczy zastępczej sami poruszają zagadnienia związane z obszarami, które wymagają poprawy, aby system pieczy zastępczej rozwijał się i by wraz z tym rozwojem następowała jego stopniowa destygmatyzacja. Najważniejszymi kwestiami wydają się być: wzrost powszechnej świadomości o roli instytucji pieczy zastępczej we wspieraniu rodziny, szczególnie poprzez zwiększenie poziomu wiedzy innych specjalistów na temat funkcjonowania rodzin zastępczych; inicjowanie pozytywnych relacji z instytucjami otoczenia społecznego i umiejętne koordynowanie wsparcia świadczonego przez poszczególne placówki; uwrażliwianie rodziców zastępczych na potrzebę korzystania ze specjalistycznego wsparcia jako niezbędnego elementu właściwego funkcjonowania nie tylko samego systemu pieczy zastępczej, ale też najważniejszych jego części składowych - rodzin zastępczych. 
Podsumowując, należy się także zastanowić, czy niedookreślenia związane z zawodem koordynatora rodzinnej pieczy zastępczej, brak spójnych rozwiązań instytucjonalnych, wytycznych metodycznych oraz jednolitych interpretacji prawnych będą sprzyjać integracji przedstawicieli zawodu i kształtowaniu się jego nowej tożsamości, odróżniającej ich od pracowników socjalnych, czy też będą zagrożeniem dla kształtującej się struktury profesji i jakości kierowanych do rodzin zastępczych, a tym samym staną się czynnikiem hamującym rozwój systemu opieki zastępczej nad dzieckiem.

\section{BIBLIOGRAFIA}

Badora S., Marzec D. (2002), Systemy opieki kompensacyjnej w zjednoczonej Europie, Kraków: Oficyna Wydawnicza Impuls.

Fengler J. (2001), Pomaganie męczy. Wypalenie w pracy zawodowej, Gdańsk: GWP.

Informacja Rady Ministrów o realizacji w roku 2016 ustawy o wspieraniu rodziny z dnia 9 czerwca 2011 r. o wspieraniu rodziny i systemie pieczy zastępczej z dnia 31 lipca 2017 r., www.bip. kprm.gov.pl (dostęp: 02.10.2017).

Informacja Rzecznika Praw Dziecka z badania sytuacji opiekuńczo-wychowawczej oraz prawnej dzieci w wieku 0-10 lat przebywających w instytucjonalnej pieczy zastępczej z dnia 16 grudnia $2016 \mathrm{r}$.

James R., Gilliland B. (2008), Strategie interwencji kryzysowej, Warszawa: PARPA.

Kanios A. (2016), Praca socjalna z rodzina problemowa. Perspektywa metodyczna, Kraków: Oficyna Wydawnicza Impuls.

Kantowicz E. (2001), Elementy teorii i praktyki pracy socjalnej, Olsztyn: Wydawnictwo Uniwersytetu Warmińsko-Mazurskiego.

Musioł S., Twardowska M. (2011), Pracownik socjalny-profesjonalne działanie na rzecz osób wykluczonych, Warszawa: Instytut Rozwoju Służb Społecznych.

Patela-Owczarek A. (2014), Organizacja rodzinnej pieczy zastępczej w Warszawie, „Problemy Opiekuńczo-Wychowawcze", nr 1.

Raport z oceny realizacji ustawy o wspieraniu rodziny $i$ systemie pieczy zastępczej. Wyniki analiz i badań jakościowych i ilościowych (2016), Warszawa: Koalicja na rzecz Rodzinnej Opieki Zastępczej.

Stenogram wypowiedzi RPD Marka Michalaka z posiedzenia nr 8 w dniu 14 stycznia 2016 r., www. sejm.gov.pl (dostęp: 02.10.2017).

Szmagalski J. (2009), Stres $i$ wypalenie zawodowe pracowników socjalnych, Warszawa: Instytut Rozwoju Służb Społecznych.

Ustawa z dnia 9 czerwca 2011 r. o wspieraniu rodziny i systemie pieczy zastępczej (Dz.U. 2017, poz. 697).

Wosik-Kawala D. (red.) (2012), Rodzinne i instytucjonalne środowiska wychowawcze, Lublin: Wydawnictwo UMCS. 


\section{SUMMARY}

Amongst many changes, which have followed foster care system reorganization, the emergence of a Family Foster Care Coordinator profession seems to be a very important component. The article presents tasks which are entrusted to coordinators, activities they actually perform, and also common problems faced by foster families. The empirical part of the article highlights observations from specialists hired as coordinators, and their perceptions about difficulties and threats of their profession. The author presents the most important directions of transformation, and challenges that foster care has been facing. Conclusions presented in the article may serve as a contribution to designing changes for the local family support systems.

Keywords: foster care; social support; family 